\title{
Àsuiwàda Principle and Inter-Ethnic Conflict in Nigeria
}

\author{
Yunusa Kehinde Salami \\ Department of Philosophy \\ Obafemi Awolowo University, Nigeria \\ yunusalami@gmail.com
}

\begin{abstract}
This paper examines the àsùwàdà principle as an indigenous social theory, which is based on alásùwàdà, a body of doctrines according to which the creator of human beings and everything in nature, dá (created) individual human beings as $\grave{a}$-sù-wà (beings who can only live successfully as part of a human group with a purpose). By establishing a teleological or purposeful unity and interconnectedness among all human beings, the àsùwàdà principle suggests that all human beings are created to be gregarious in nature and enjoy the best ìwà (existence or character) when they sù-wà (live in group). This paper interrogates the àsùwàdà principle in relation to the problem of ethnic conflicts in Nigeria. The paper concludes that if as human beings, we are dá (created) to be àsùwà, then, with the complementary ideas of alájọbi, alájọbé, and ifogbọntáyése, ethnic pluralism should not necessarily lead to ethnic antagonism or conflict.
\end{abstract}

Keywords: Àsùwàdà, Ethnicity, Pluralism, Àjọbi/Àjogbe, Conflict. 


\section{Introduction}

This paper examines the Asuwa da principle as an indigenous social theory, which is based on alásuiva dà, a body of doctrines, according to which the creator of human beings and everything in nature, dá (created) individual human beings as $\grave{a}$-su-wà (beings who can only live successfully as part of a human group with a purpose). By establishing a teleological or purposeful unity and interconnectedness among all human beings, Asu'wà dà principle proffers that all human beings are created to be gregarious in nature and enjoy the best i $w a$ ' (existence or character) when they su-wà (live in group). This paper will examine the A'su'wa' a principle in relation to the problem of ethnic conflicts in Nigeria. The paper will conclude that if as human beings, we are $d a{ }^{\prime}$ (created) to be àsuiwa (beings who can only successfully as part of a human group with a purpose), then, with the complementary ideas of alajọbi, alájogbé, and ifogbọntááyesse, ethnic pluralism should not lead to ethnic antagonism or conflict.

\section{Àsùwàdà Principle}

The Asuiwa'da principle is a social theory, which Aki wọwo developed from a Yoruba poetry, which he identifies as àyájọ alásuwàdà, which is "usually recited... at a rite-of-consecration called akintẹlú performed when a new human settlement is to be founded" (Akiwowo 1990, 104). Aki wowo referred to alásuwa da as "the author of all things" $(1986,348)$ in heaven and on earth. According to Aki wọwọ, "The source of all earthly forms of i wà-susu (bunched of existence) is the divine being called Olọfin Otete (ruler of the palace of infinite spaciousness). He or she is addressed as Alásuiwà (the author of all things)" $(1990,108)$. Mákindé succinctly gave an analysis of Aki wọwọ's concept of àsuiwàd,

A'su'wàda' is derived from ìwà (a state of being, existence, or character in a perpetual state of development; suiwàda, to come together or co-exist for a common end or pupose) and Asu- $i$ wà-dà (literally meaning that which kneads or moulds $i w a$, i.e. beings, states of existence or characters so that they can live together in harmony for a purpose or common end $(1990,121){ }^{1}$

This complies with Aki wọwộs interpretation of àsuiwàdà as "purposive

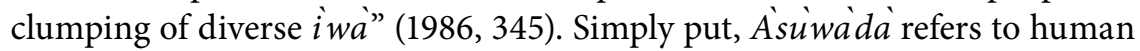
beings as social, political and gregarious animals. They are beings who can

1 The issue of teleology or group purpose is well discussed and assessed in Lawuyi and Taiwo 1990, and Ademoyo (2009). 
only realize their goods and life purposes and objectives when they live in groups with others. They are beings who cannot achieve their worldly goals atomistically as individuals in isolation from the society. Aki wọwọ calls this the sociality of man, where by sociality he means "the quality or fact of being able to live and grow in communities...the quality of being able to suivada (come together for a common end; to co-exist)" $(1983,16)$. This account clearly "distinguishes between àsuiwà (coexistence) and àsuiwàdà (the fact of being together for a purpose)" (ibid, 16-17).

This clumping of diverse $i w a$ or bunched existence is not restricted to the humans. It is replicated among animals and plants. This is aptly captured in some lines of the poem such as:

56. Asuiwa is what the oyin are

57. A'suiwa' is what the àdò bees are

58. The eéran leaves grow in Asuiwà

59. Asuiwa is what broomsticks form

60. It is in Asuwa that the e'ran leaves grow in the aare

61. Asuiwa' is what elégíri birds form

62. It is the coming together of a multitude of men

63. That we know as warfare

64. It is as Asuwa that one encounters the grassland

65. It is as Asuwa that locusts invade a farmland... $(1990,108)$

For Aki wọwọ, these instances, among many others, "list forms and types of life forms or beings which continue in- being as a result of their conformity with the principle of asuwa" (1990, 109). Following the lines, one can see that the principle of asuiva is not restricted to the human beings. It is extended to other forms of life such as "oyin (bumble bee), àdò (honey bee), the human hair, trees, grasses, ants, leaves, birds, locusts, and even man-made àsuiwà, such as broomsticks, and corps of fighting men" (ibid.). This is why "In several asuiwa the termites colonize their mounds. In several asuiwa we encounter the ekunkun by the riverside. It is as asuwa that we find the làbelàbe by the waterside" (ibid.).

In addition to the principle of bunched existence in the asu'wada principle is the idea of collective goodness. It is part of the asuiwa' a principle that collective good reigns (ibid, 110-111). This can be seen from some of the lines of the oral poetry such as:

108. On the day, he was to release

109. Existences on the Earth

110. One particle of dust became

111. A basketful measure of dust

112. A basketful measure of soil became the earthcrust 
113. Dews pouring lightly, pouring lightly

114. Were used to mould the earth

115. Dews pouring heavily, pouring heavily

116. Were used to mould the earth

117. So that ire-gbogbo may multiply on it

118. Ire-gbogbo took the shape of asuiwa'

The principle emphasizes collective goodness, which can only be attained in the harmonious coexistence contained in asuiwa. This principle is stressing the point that there can only be goodness in society when a bunch of characters forms a bunched existence. They need goodness to regulate the differences in character. More than that, the principle emphasizes the point that it is in àsùwà (bunched existence) that goodness actually resides. Outside of this (àsùwà) there is no good.

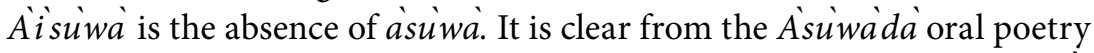
that at the beginning of creation, all earthly beings were created with the $A$ suiva'd such that they can only realize the goodness of their beings in the harmonious coexistence as a group. A isu $_{\text {iwa }}$ was not part of the original creation. "Ire-gbogbo is in the form of asuwa" (ibid, 111). Ire-gbogbo here means collective good. The line is simply saying that collective good is in the form of

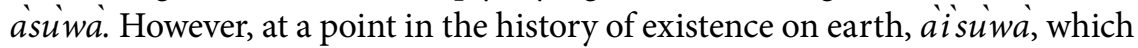
means absence of bunched existence, was introduced into the natural order. According to the oral poetry, $\dddot{a}^{\prime}$ suww in form of "error, or moral offence... began when Yankangi strayed away from ire-gbogbo" (ibid.). Some lines of the poetry state the beginning of the disorderliness thus:

129. There is no luckless head in a companion of travelers

130. For ire-gbogbo is in form of asuiwa

131. Yankangi alone it was

132. Who strayed for a moment from his companion

133. Was said to have stolen irú to eat

134. From Mother Olugamo's tray in heaven

This straying away from companionship by Yankangi is regarded as self-alienation which negates the original asuwà social order naturally planned for human existence. Thus, "According to the principle of asuiwa, there was no error at the emanations of earthly beings. Error, 'sin', or self-alienation, was introduced into the natural order when Yankangi inadvertently turned his back against his original community to be alone in order to enjoy alone the provision that was intended for the common good" (ibid, 112).

According to Akiwọwọ, "self-alienation, called $\dddot{a} i$ sùwa, was the first prototype of error or sin, of what we regard in sociology as social deviation or social pathology...it is imperative for the common good that there be always 
sociality among all elements in creation" (ibid, 112-113). This principle emphasizes the point that we can only find the substance of goodness in the community of creatures. This is because, "The whole earth is a macro-community in which human settlements of varied sizes and densities are micro- communities" (ibid, 112). The àsuiva dà principle, no doubt, stresses the importance of social harmony in human communities while, at the same time, stressing the evil consequences of one part of the community alienating itself from the others.

\section{The Nigerian Multi-National State}

Nigeria is a hotchpotch of different ethnic nationalities. It is clear that the people of Nigeria "are in different geo-political settings with their multifarious experiences about the world" (Salami 2004, 398). Nigeria is a nation that is composed of several ethnic nationalities. This "conglomeration of different ethnic nationalities" (ibid.) makes Nigeria an ethno-culturally pluralist nation-state, which "is fragmented into different ethnic, commune-cultural, or local loyalties as well as different corresponding socio-cultural allegiance and commitments" (ibid, 399).

The idea of ethnic pluralism expresses the fact that as social and gregarious animals, human beings belong to different groups which "are organized by some distinct sets of customs, techniques and traditions" (ibid.) that form the culture of a people. In this case, "members of the same ethnic group are said to share the same mother tongue, blood relationship, ancestral lineages, and geographical proximity, among others. Members of an ethnic group are born into the group and they necessarily belong to it (Maclean 1991, 325-326). For instance, "the cultural tie between the Hausa of Nigeria and Niger may be greater than contacts between Hausa of Nigeria and Jukun of Nigeria" (Udo $1980,10)$. This factor of cultural ties is so strong that "Long after the establishment of British and German rule, many chiefs in the German-controlled areas of Adamawa continued to pay tribute and do homage to the Fulani Emir of Yola, the former ruler of Pre-colonial Adamawa" (ibid.). Ethnic pluralism can also be explained by the usual concentration of different ethnic groups on different and separate spatial locations. Given this fact, "the different ethnic groups are opened to different geographical locations, which sometimes carry with it the differences in weather and activities, of the different ethnic groups, which settle in different locations" (Salami 2004, 400).

The differences in the ways the different ethnic groups go about the business of their lives is greatly influenced by the differences in weather among them. This is explained by the fact that the group in the south are bound to have more water round the year, while the counterpart "in the North are 
exposed to the dry North-East trade winds from the Sahara Desert which is for most of the year, hot dry" (ibid.). The differences in weather creates differences in the lives of the different ethnic groups that constitute the Nigerian nation-state. For example, "the long dry season when water and grazing for cattle is scarce has made it necessary for the Fulani cattlemen to adopt a nomadic mode of existence" (ibid.). The differences in lives and in the cultural milieu of the different ethnic nationalities have, in no small measure, influence the ways they go about meeting their material conditions of existence. This, in effect, provides different social and cultural ties, which separate the different ethnic nationalities from one another. The consequence of this is the problem of ethnic pluralism in which citizens emphasize their different ethnic nationalities and demonstrate their allegiances as well as loyalties to their ethno-cultural groups at the expense of the corporate identity of the Nigerian state (ibid, 400-401).

\section{Ethnicity and the Nigerian Multinational State}

Ethnicity is nothing but the fact of belonging to an ethnic group (Gbadegesin 1981, 3-5). Ethnicity simply says that a nation is made of several ethnic nationalities. "It expresses the fact that Nigeria is made of such linguistic, cultural, or ethnic groups as Birom, Tiv, Igbo, Edo, Yorubá Ijaw, Jukun, and Hausa among others" (Salami 2004, 401). The classification of people into an ethnic group is based on language sharing, blood relationship or ancestral linkages. For each ethnic group, there is a lineage traceable to a common ancestor. For instance, members of the Yoruba ethnic group will trace their ancestral lineage to Oduduwà. The ancestor is considered the progenitor of members of the ethnic group. ${ }^{2}$

Ethnicity expresses the fact of belonging to different ethnic groups. This suggests social and cultural pluralism. It explains the fact that in a nation, like Nigeria, where the concept is applicable, there are more than one ethnic group forming the nation. To have a state or nation, there are requirements such as an occupation of certain geographical location with specified boundaries by a sizeable population of human beings who are under the rule of some who have the authority to direct the affairs of the state. Such a community must also enjoy sovereignty or self-governance (Fishman 1972, 2). Establishing a nation or a state-community requires the coming together of people of different ethnic origins who have different ancestral linkages, languages and blood relationship under one administrative umbrella (Aristotle 1963). A positive link can be established between ethnicity and nationhood because there is hardly any nation that is ethnically monolithic. Since nations are formed

2 Wsevolod (1971) and Francis (1974). 
from a conglomeration Fishman of different ethnic groups, it is plausible to claim that ethnicity is significant to nationhood. With this, we can treat ethnic groups as integral parts of the nation (Isaacs 1975).

In spite of the aforementioned positive link that may be established between nationhood and multiplicity of ethnic groups, some critics assume that multiplicity of ethnic groups may be inimical to the idea of nationhood by constituting a basis for inter-ethnic conflict. The point raised by the critics of multiplicity of ethnic groups is that in an ethnic pluralist state like Nigeria, "people show more allegiance to their ethnic groups than the nation as a whole. People find their primordial affinities and attachments as well as their ancestral linkages stronger than the political ties in nationhood" (Salami 2004, 401).

\section{Inter-Ethnic Conflict and the Nigerian Polity}

The Nigerian polity shows some examples of how ethnic pluralism has almost balkanized the Nigerian state. Nigeria as a nation has a heterogeneous ethnic heritage. The number of ethnic groups in Nigeria is estimated to be two hundred and fifty. Among this estimated number of ethnic groups, four occupy a position of prominence. The four prominent ethnic groups are "Yoruba in the West, Hausa and Fulani in the North, and Ibo in the South-East. These four are reckoned as constituting sixty percent of the population. The Hausa comprise the largest single group in the North followed by the Fulani. The Yoruba dominate Ògùn, Òndó, Ọyọ, Ộșun, Lagos, and Èki tì states. The Ibo dominate Anambra, Imo, Abia, Enugu, Cross River, and Bayelsa States."3 Apart from these four dominant ethnic groups, there are some other minor ethnic groups such as "Kanuri in Bauchi and Borno states, the Edo in Delta and Edo states, the Ibiobio in Cross River and Akwa Ibom states, the Ijaw in Rivers, Bayelsa, Edo,and Delta states, the Tiv in Benue and Plateau states, the Nupe in Niger, Kebbi, and Sokoto states, the Efik in the East, and so on" (Salami 2004, 402). This diversity in ethnic lineage, no doubt, constitutes bases for diversity in the politico-economic relation in Nigeria (ibid.).

The rise in the number of ethnic militia and warriors signifies one of the negative impacts of ethnic pluralism on the Nigerian political entity. In Nigeria, "the inter-ethnic agitation is no longer restricted to the major ethnic groups... In Nigeria today, inter-ethnic suspicion and conflict is diverting the attention of the citizens from the pursuance of the national goal and objective" (ibid, 403). In a multi-ethnic Nigeria, an Ibo from Eastern Nigeria or a Yoruba from the West will be reluctant "to settle down as a Nigerian in the North, which is the geographical and cultural region of the Hausa, Fulani, or

3 Ikime (1980), Ofonagoro (1978), Nnoli (1978), Fashina (1998). 
the Kanuri" (ibid.). In the same vein, it is becoming difficult for the Hausa, Fulani, or the Kanuri to be assimilated to the way of life in the Eastern and Western Nigeria. Furthermore, a Nigerian from a different ethnic group can only get a temporary appointment, if at all, in some other parts of the country that belong to some other ethnic groups.

Ethnic pluralism and its attendant problem of diversity have made it difficult for citizens of Nigeria to move freely throughout Nigeria or reside freely in any part of Nigeria of their choice. For instance, "cases of discrimination in the provision of goods and services abound with citizens making complaints to governments whose hands seemed to be chained" (Gbadegesin 1991, 101). Besides the issue of discrimination, national programs are usually beclouded by mutual suspicions and cry of marginalization: "For example, when one ethnic group controls the political machinery of the state, other ethnic groups find it difficult not to feel marginalized" (Salami 2004, 403).

\section{Ethnicity and Ethnicism}

It may be interesting to ask whether ethnicity needs be inimical to nationhood or whether the fact of a nation having multiple ethnic groups should ordinarily lead to inter-ethnic conflict. Contrary to the apparent connection between multiple ethnicity and inter-ethnic conflict, as we have in Nigeria; "ethnicity does not portend negation to nationhood. Rather, ethnicity as a biological concept is neutral. It has no political or class bias" (ibid, 403; Gbadegesin 1991, 87). It has been observed that "the important fact about an ethnic group is the involuntary and irrevocable nature of its membership. An individual is ascriptively the child of his or her parents, and the fact cannot be changed, no matter how he or she may be dissatisfied with it" (Gbadegesin, 4). This excludes the element of choice in ethnicity. An ethnic group should be seen, primarily, as a biological group and should not be confused with a political group. It expresses a biological connection. "The upshot of this is that ethnicity does not express lack of national identity or call for inter-ethnic conflict (Salami 2004, 404). A nation can be made of different ethnic groups and still remain cohesive and maintain a common corporate interest not distracted by ethnic considerations. In this case, "ethnicity is just a neutral concept. It merely expresses a biological relationship among members or citizens of a nation... neither ethnic homogeneity nor ethnic heterogeneity is sufficient to produce national unity or diversity respectively" (ibid.).

Nevertheless, problem can arise between ethnicity and nationhood when ethnicity is politicized. In other words, "it is when citizens begin to manipulate their facts of belonging to different ethnic groups, for their political and economic ends, that we begin to lose a sense of national identity. This fact 
of politicizing ethnicity is what is referred to as 'ethnicism"' (ibid, 405; Gbadegesin, 87). According to this view, the origin of inter-ethnic conflict in a multi-ethnic society "is not the fact of belonging to different ethnic groups but something more hidden, such as economic needs, psychological attitudes or some internal patterns of the group structure...ethnic antagonism is created by the human beings in the community" (Gallo and Molina 1991, 62). The inter-ethnic conflict as we have it in Nigeria is a product of the use to which ethnicity is put. In this case, "ethnic elites manipulate and politicize ethnicity in their various struggles to partake in the sharing of the national cake. This politicization of ethnicity militates against national identity and harmony in an ethno-cultural pluralist Nigeria" (Salami 2004, 405). Based on this politicization, there are multiples of ethnic militias from as many as the number of ethnic groups existing in Nigeria. This has led to a devastating conflicts at various periods in the life of Nigeria. At present, there is the resounding secessionist outcry for a Biafran Republic from the Igbo ethnic group while the Hausa-Fulani ethnic groups are holding the North as an ethnic site that non-northerners cannot inhabit.

\section{àsùwàdà Principle as a Panacea for Inter-ethnic Conflict}

Although ethnicity does not in itself presuppose any form of separatist or secessionist preoccupation, yet, if it is over-politicized, it can lead to the disintegration of national unity and identity. This presupposes that ethnicity needs to be dealt with creatively. Ethnic pluralism can be turned into a positive force, what is required is mutual respect among the various ethnic groups. For Mclean, "the different ethnic groups should engage in cooperative, but competitive interaction for the positive development of the society" (1991, 333). In search of a creative way of dealing with the problem of ethnicism and the attendant problem of inter-ethnic conflicts in Nigeria, the asuiwà principle becomes handy. The problem before us is how to resolve the incompatibility between ethnic pluralism and national harmony. The fact of the multiethnic and multicultural nature of the Nigerian state and the attendant problem of interethnic conflict call for conscious efforts at fostering interethnic peace and harmony.

Àsuiwàdà, Alá jọbi', and Alájoggé are concepts which, if properly operationalized, can provide suggestions to move Nigeria out of the present ethnic conflict and disharmony. Asuiwàd Eniyàn already presupposes bunched existence and teleological co-existence. Ásu'wà dà oral poetry already establishes the principle according to which humans and animals were created to manifest bunched existence or group existence as a result of having been created from the same dust and the need to meet the individual and collective goals as 
a group in a gregarious existence. Unlike the Hobbesian account of the origin of man in an atomistic and individualistic state of nature, from which humans later escaped, because of the undesirable nasty and brutish nature of such a state to build a commonwealth; the àsu- $i$ wà-dà principle states that human beings and other animals were originally created to live together in group to

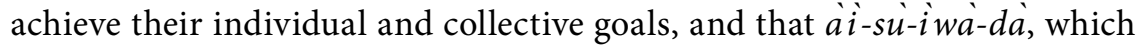
means self-alienation and separation or deviation from group existence, is an aberration that later came as an error on the part of human beings.

To achieve this bunched existence of different ethnic groups in the attainment of nationhood in a multinational state, alájobí and alá jogbé are handy. Going by Akiwọwộs discussion of àsùwàdà in conjunction with his discussion of the twin concepts of àjobl' and àjogbé, the multinational and multicultural nature of the Nigerian state can be explained and understood. While the concept of ajobli may express the fact of belonging to a family and an ethnic group in which people share the same blood, language and ancestral lineage, àjogbe expresses the fact of ethnicity in which various such groups co-exist in a community. ${ }^{51}$ Corresponding to these concepts are also alájobí and alájog$b e$. These two important concepts and notions capture the condition of several families or ethnic groups sharing the same geographical and political space.

The question is whether the possibility of co-existence guarantees harmonious co-existence among different families and or ethnic groups or ethnic nationalities. One good thing in this case is that human beings were originally created to live a bunched existence. The self-alienation, which constitutes the original sin here, is wrong and simply needs to be put back to normal. Prima facie, it seems as easy as to simply use moral education to let people of different ethnic nationalities realize the originally bunched nature of our existence and the abberative nature of self-alienation or inter-ethnic conflict. The moral education will involve the emphases on how to restore the original mutual trust and confidence that the self-alienation has taken away from the various groups of alájobí, which join to form the Nigerian alá jogbé.

The assumption underlying this proposal is that if human beings know what is right they will do what is right. In other words, once everyone knows that originally we were meant to co-exist for the general goal of the multinational state, everyone will work towards the harmonious mutual coexistence rather than fanning the ember of interethnic disaffections. Much as the method of moral education promises some level of efficacy in bringing harmony back to the present state of anomy, the problem is that it is not usually the case that human beings cannot knowingly do that which is wrong. In other words, a person may know that an action is wrong and still go ahead to do it or cause it to happen. 
This raises the question of the problem of the will. This is a case in which, in spite of the knowledge of the distinction between right and wrong, one's will is not strong enough to resist doing the wrong. This is to argue that mere moral education about the àsuivàda may not be sufficient to guarantee harmony in a fractious relationship. However, the question can be raised that if by nature we are to necessarily live in a bunched existence, why do we find ourselves in this disharmonious corporate entity called Nigeria. The answer may be that as long as there is possibility of self-alienation, the bunched-existence is not built on necessity but on capability. If we go by this, we will be saying that àsuiwà $a_{a}$ created human beings with the capacity to $s u-w a$, or have bunched existence; it did not create them to necessarily have a bunched existence. This necessity-capability distinction may weaken the prospects of the àsuivada principle serving as a panacea to inter-ethnic conflicts. Again, there is the collective goal of all the alájogbé, and by extension the collective goal of the nation that fosters the overall goal of the aggregate of co-existing ala jobí. In other words, even if the necessity of bunched existence is watered down to mere capability for bunched existence, there remains the need for bunched existence for the attainment of the national goal. In a situation in which, as explained in the àsuiwà principle, individual goals are only achievable through the collective goal, there is the duty to harmonize the interests of the different ethnic groups making up the Nigerian state.

Attempts should be made to clarify that the kind of collective goal that the àsưada principle emphasizes is not the type that suggests totalitarianism. The collective goal, engendered by the idea of bunched existence in the àsuiwàdà principle, recognizes the individuality. However, it holds that the specific, private and personal content of the individuality are connected to those of others in the larger community (Ademoyo 2009, 26). In other words, the good of the individual is connected to the good of the community; the individual ethnic groups need the co-existence or the togetherness in the nation-state to achieve their individual goals.

In spite of the self-alienation that came as the first sin that diverted some component parts of the nation from the original collective goal of the nation, which is embedded in a bunched existence, the fact remains that the society needs a bunched existence for its perpetuity. Here arises the 'is/ought' question. Going by the àsuivà à principle, the various ethnic constituents of the Nigerian multinational state ought to be in harmonious bunched existence, but, in reality the Nigerian nation-state is now in total disharmony. There is the IPOB/MASSOB in the South-East agitating for a Biafran nation, the Arewa Youth with its threatening presence in the North, the various Niger delta militant groups fighting for resource control, among others. The possibility of the problem of "is/ought" distinction and the way out of it is already 
embedded in the àsuiwa'da principle, which takes the collective goal of the collective as self-perpetuity and includes the idea of societal self-reinvention. The idea of societal reinvention presupposes the possibility of a break in the chain of bunched existence, which may be a temporary death of the Asuiwa'd spirit. The difference between the societies that cannot continue to perpetuate themselves and those that can will reside in their ability to reinvent themselves (ibid, 27).

Given the current comatose state of the asuiwa'da spirit in the Nigerian multi-national state, the question is the way out. This brings to bear the idea of ifogbọntáyése, which, for Akiwọwọ, means "using wisdom to remake the world" (1983, 4), and for Makinde, means "the conscious employment of human knowledge, reason and wisdom for the understanding and improvement of the world" (1990, 129-130). With ifogbọntáyése as a concept that is part of the Asuwada principle, there is the opportunity for human beings to creatively employ deep intellectual thought to examine the why and how of the deviation that is engendered by self-alienation. İfogbọntáyése becomes a tool for the "development and improvement of society and the general condition of humanity" (ibid, 131).

The way forward is to use wisdom and deep thought to reinvent the nation from the present aisuwa back to its original state of asuiwà. Critical and rational thought will enable ease of studying and appraising how and why citizens resorted to self-alienation and thereby deviated from the original norm of bunched existence. This reappraisal will show the problem experienced by the members that prompted them to self-alienation, and help to fashion out explanations to resolve the problems. With ifogbonntáyése, it will be clear that Nigeria is a federalist state in which the different alájobi and alájobi constitute different federating units. If the different federating units are in disarray, disharmony, and self-alienated, the thought should be about the root cause of the disaffection. The discovery of the factors and causes of the disaffections will constitute a basis for resolving the disharmony. The basic feeling among the various ethnic groups, which are combinations of different alájobí and alájogbé, is that of distrust and marginalization, which result from social injustices. The question now is how to restore trust and harmony to enable bunched existence and realization of the collective will or goal of the Nigerian state.

One prominent wisdom (ogbọn) in the attempt to reinvent the society (tún ayé se) is to think of how to restore mutual respect and remove all those factors that brought mutual suspicions among the federating units. One of such reasons may be the idea of geniune federalism and devolution of power. This will be contrary to the present arrangement in which power is over concentrated at the top at the expense of the federating units. The present 
arrangement raises inter-ethnic suspicions, especially when the federal power is seen to reside more in one part of the country than the others. The use of reason and wisdom is required in removing this lopsidedness in the arrangement of power and the attendant unjust distribution of wealth. Depending on how correctly we allow the use of reason and wisdom to appraise and tackle these causes of disaffection, we are at the verge of restructuring or reinventing the Nigerian society to attain the harmony and mutual trust required for a bunched existence which was the way we as people were originally created to live and exist.

\section{Conclusion}

This paper examines the àsuiwàd principle as an indigenous social theory based on a body of doctrines according to which human beings as well as all other creatures, are created such that they require bunched existence in order to achieve both their individual and collective goals. The paper discusses this àsuiva da principle in relation to the problem of ethnic conflicts in Nigeria. It finds out that, in spite of the fact that human beings were àsuiwada by nature, there came a point in the history of humans when $a \grave{i}$ suwa or deviation crept in through human's urge for self-alienation. Nevertheless, the paper concludes that despite the evil of self-alienation and its attendant problem of inter-ethnic conflict, a peaceful Nigerian state can still be reinvented with the aid of concepts such as alájọbí, alájogbé, and i fogbọntáyése.

\section{Works Cited}

Ademoyo, Adeolu (2009), "Purpose, Human Sociality and Nature in Akiwowo's Sociology of Knowledge: A Realist Interpretation," African Sociological Review Vol. 13 No.2: 16-28.

Akiwowo, A. Akinsola (1983), "Ajobi and Ajogbe: Variations on the Theme of Sociation," An Inaugural Lecture delivered at the University of Ife (Ile-Ife: University of Ife Press).

Akiwowo, A. Akinsola (1986), "Contributions to the Sociology of Knowledge from an African Oral Poetry" in International Sociology Vol. 1 No. 4: 343-358.

Akiwowo, A. Akinsola (1990), "Contributions to the Sociology of Knowledge from an African Oral Poetry" in Albrow Martin and King Elizabeth (eds.) Globalization, Knowledge and Society (London: SAGE Publications), 103-118.

Aristotle (1963), "Origin of the State, Nature of Man, Institution of Slavery" in Somerville John and Santoni, R. E. (eds.) Social and Political Philosophy: Readings from Plato to Gandhi (New York: Anchor Books), 59-100. 
Fashina, Oladipo (1998), "Reflections on the National Question," in Olorode Omotoye, et al. (eds.) Ken Saro Wiwa and the Crises of the Nigerian State (Lagos: CDHR).

Fishman, Joshua (1972), Language and Nationalism (Massachusetts: Massachusetts University Press)

Francis E. K. (1974), "The Nature of the Ethnic Group," The American Journal of Sociology Vol. 52: 393-400

Gallo, Antonio and Molina, Luisa (1991), "Cultural Pluralism and Development: The Ethnic Situation of Guatemalan Youth," in John Kromkowski (ed.) Relations Between Cultures (Washington, D. C.: The Council for Research in Values and Philosophy).

Gbadegesin, Segun (1981), "Ethnicity and Citizenship," Second Order Vol. X, No. 1\&2: 3-12.

Gbadegesin, Segun (1991), "The Politics of Ethnicity," in Segun Gbadegesin (ed.) The Politicization of Society During Nigeria's Second Republic 19791983 (Lampeter: The Edwin Mellen Press).

Isaacs, Harold A. (1975), "Basic Group Identity: The Idols of the Tribe," in Glazer Nathan and Moynihan, D. P. (eds.) Ethnicity: Theory and Experience (Cambridge: Harvard University Press), 29-52,

Lawuyi, O. B. and Taiwo, Olufemi (1990), "Towards an African Sociological Tradition: A Rejoinder to Akiwowo and Makinde" in Albrow Martin and King Elizabeth (eds.) Globalization,Knowledge and Society (London: SAGE Publications, 1990), 135-151.

Makinde, M. Akin (1990), "Asuwada Principle: An Analysis of Akiwowo's Contribution to the Sociology of Knowledge from an African Perspective" in Albrow Martin and King Elizabeth (eds.) Globalization, Knowledge and Society (London: SAGE Publications, 1990), 119-134.

McLean, G. F. (1991), "Discussions," in John Kromkowski (ed.) Relations Between Cultures (Washington, DC.: The Council for Research in Values and Philosophy).

Nnoli, Okwudiba (1978), Ethnic Politics in Nigeria (Enugu: Fourth Dimension) Ofonagoro Walter I., et al (eds. 1978), The Great Debate: Nigerian Viewpoints on the Draft Constitution 1976/1977 (Lagos: Daily Times of Nigeria)

Salami, Yunusa Kehinde (2004), "Ethnic Pluralism and National Identity in Nigeria," in Rodney D. Coates (ed.) Race and Ethnicity: Across Time, Space and Discipline (Leiden: Boston: Brill, 2004), 397-406.

Udo, Reuben (1980), "Environments and Peoples of Nigeria," in Obaro Ikime (ed.) Groundwork of Nigerian History (Ibadan: Heinemann Educational Books, 1980), 7-24.

Wsevolod, Isajiw (1974), "Definition of Ethnicity," Ethnicity Vol. 1: 111-124. 